\title{
Perineal Electric Burn Reconstruction Using Modified Thoraco-Umbilical Flap*
}

\author{
Bin Xu, Jinlong Wang \\ Department of Plastic Surgery, The Affiliated People's Hospital of Jiangsu University, Zhenjiang, China \\ Email:xubinfen@126.com
}

Received 2 January 2016; accepted 9 July 2016; published 12 July 2016

Copyright (C) 2016 by authors and Scientific Research Publishing Inc. This work is licensed under the Creative Commons Attribution International License (CC BY). http://creativecommons.org/licenses/by/4.0/ c) (i) Open Access

\begin{abstract}
Perineal reconstruction is an essential component of the overall treatment plan of perineal electric burn, but it is a very difficult and complex job. The modified thoraco-umbilical flap may be a perfect way of repairing perineal area. It is based on the deep inferior epigastric artery and vein and the superior epigastric artery and vein, which look like the "reverse TRAM flap". The large flap could be fashioned into a perfect perineal area without the need for free flap. It left a satisfactory donor scar, and it avoided the need to change the patient's position during the operation. Four cases were reconstructed by modified thoraco-umbilical flap after perineal electric burn, and all of them were satisfied with the results. The modified thoraco-umbilical flap has been emerged as a very useful reconstructive tool and is particularly valuable in reconstruction of the perineal electric burn.
\end{abstract}

Keywords

Perineal Electric Burn, The Modified Thoraco-Umbilical Flap

\section{Introduction}

The perineal area serves an important function. Perineal reconstruction is an essential component of the overall treatment plan of perineal electric burn. When perineal electric burn occurs, it is very hard to reconstruct. Skin graft is not the best way because the contract scar will happen. Local flap transfer may be the best way for perineal electric burn, but there is no proper local flap when the local skin, muscle and artery were destroyed [1]. Due to the special function and appearance of the perineal area [2], reconstructive options for perineal trauma are not very satisfactory.

\footnotetext{
*The study was approved by ethics committee of our hospital, and all the 4 patients signed informed consent before the operation.
} 


\section{Methods}

The TRAM flap has emerged as a very useful reconstructive tool and is particularly valuable in reconstruction of the breast following masterctomy [3] [4]. From the point of view of form, the modified thoraco-umbilical flap looks like the "reverse TRAM flap", is based on the deep inferior epigastric artery and vein and the superior epigastric artery and vein [5]. Flaps are typically marked approximately $12 \mathrm{~cm}$ high at the midline and extend approximately 22 - $24 \mathrm{~cm}$ laterally from the midline (Figure 1). The modified flap can extend the midline if there is necessary. The large flap could be fashioned into a perfect perineal area without the need for free flap. It left a satisfactory donor scar, and it avoided the need to change the patient's position during the operation (Figure 2). The modified thoraco-umbilical flap has emerged as a very useful reconstructive tool and is particularly valuable in reconstruction of the perineal electric burn.

\section{Case Report}

Four cases were electrician, and were hurt by electric when they sat on the ladder. Four cases were reconstructed by the modified thoraco-umbilical flap, and all patients were satisfied with the results. With the patient in a supine position, a doppler probe is used to identify the deep inferior epigastric artery and the superior epigastric artery. The size and the shape of the flap were designed according to the wound area of perineum. During flap harvest, the superficial inferior epigastric vessels are approached first. The anterior rectus sheath is opened around the perforators and the vessels are carefully dissected down through the rectus muscle to the deep inferior epigastric artery and vein. The flap was transferred from the subcutaneous tunnel. All of the patients were satisfied with the function and appearance of the flap.

\section{Discussion}

The reconstructive goal of perineal trauma is to obtain durable coverage and function. Axial pattern skin flap and local random flap are the main ways for perineal area. But to the electric burning patients, the wound area are large and irregular, the soft tissue and artery near the wound area are often destroyed, local axial pattern skin flap and local random flap are very difficult to be designed and peformed. The modified thoraco-umbilical flap

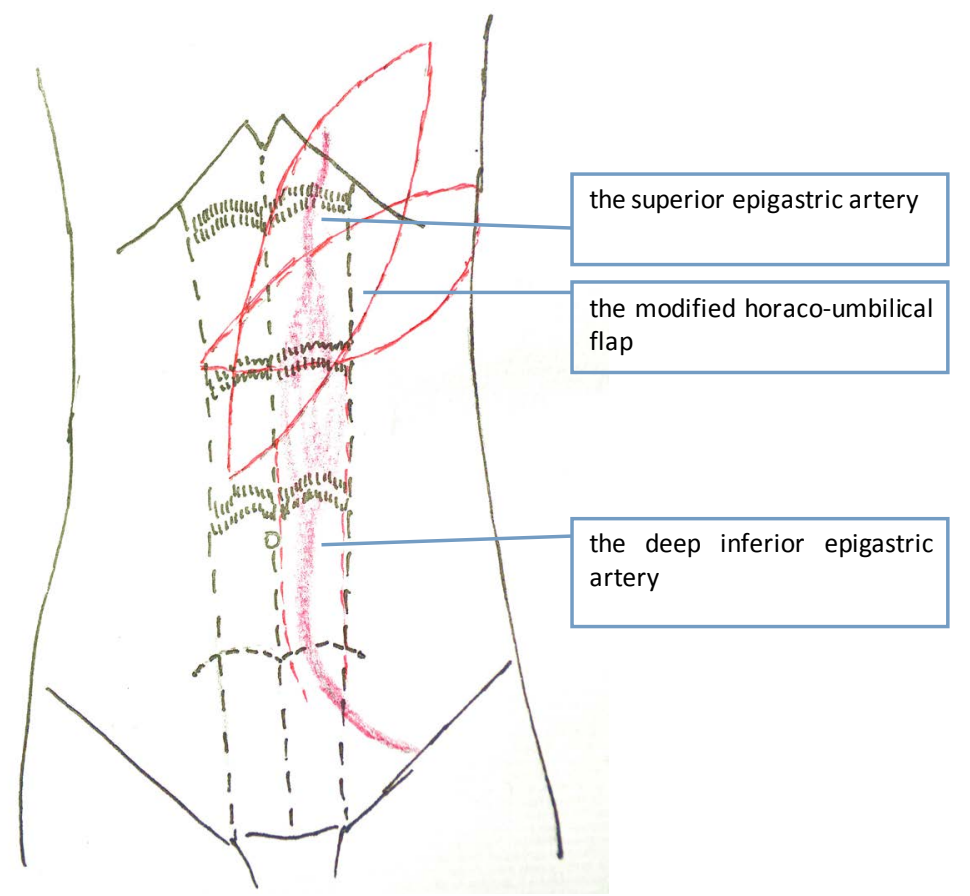

Figure 1. The modified horaco-umbilical flap is based on the deep inferior epigastric artery and vein and the superior epigastric artery and vein. Flaps are typically marked approximately $12 \mathrm{~cm}$ high at the midline and extend approximately $22-24 \mathrm{~cm}$ laterally from the midline. 

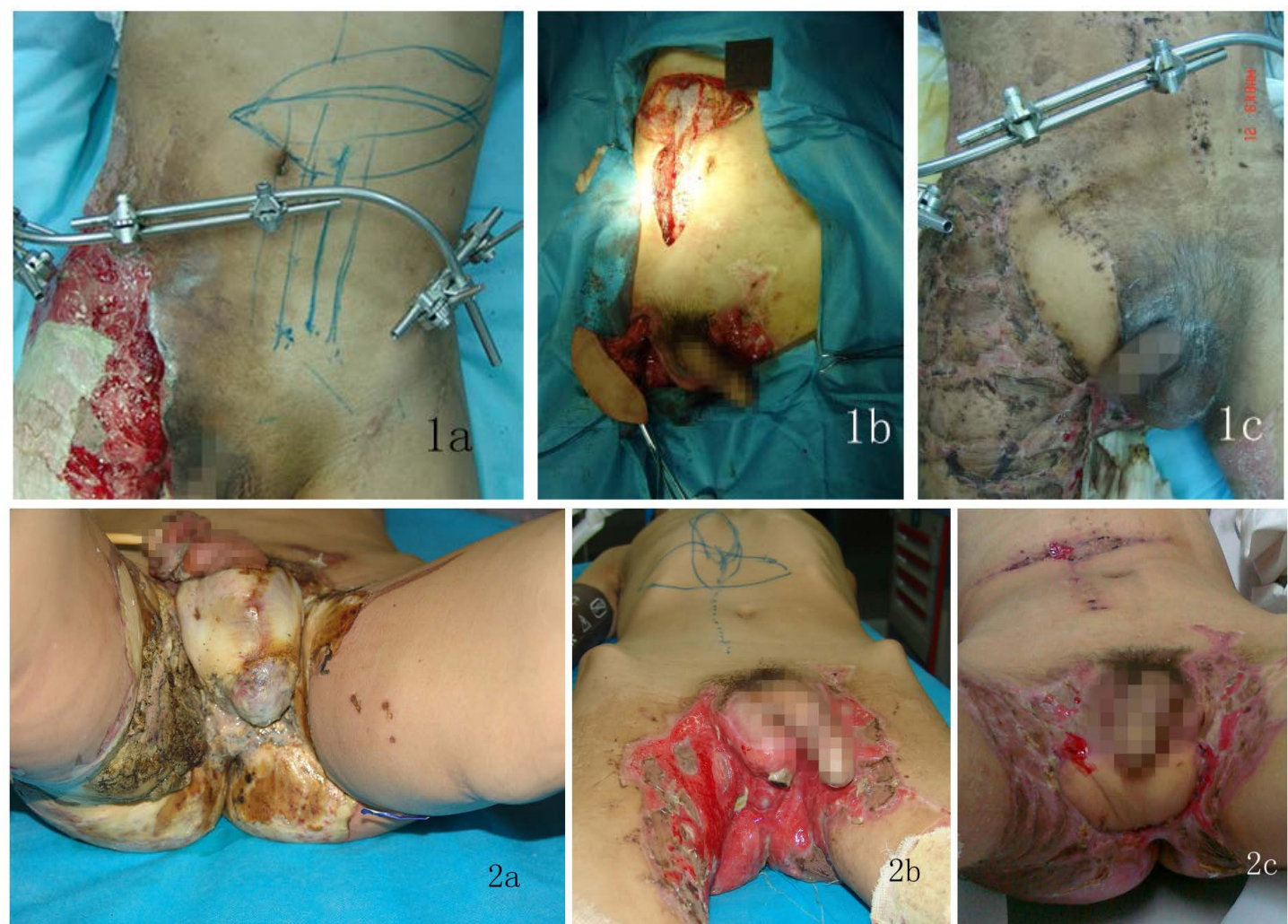

Figure 2. (1a) the serious perineal trauma after electric burn; (1b) the modified thoraco-umbilical flap was transferred to perineal area; (1c) the appearance of the flap after 4 weeks. (2a) the electrical injury of perineal area; (2b) the perineal trauma area was repaired by the modified t horaco-umbilical flap; (2c) the appearance of the flap after 3 weeks.

may be the perfect flap to repair perineal, especially to the serious and large perineal trauma. In addition, the modified thoraco-umbilical flap can extend the midline and be more flexible compared to the traditional thoraco-umbilical flap.

\section{Conclusion}

The modified thoraco-umbilical flap is a very useful reconstructive tool for the reconstruction of the perineal electric burn, and this way is worth promoting.

\section{References}

[1] Tiengo, C., Castagnetti, M., Garolla, A., Rigamonti, W., Foresta, C. and Azzena, B.J. (2011) High-Voltage Electrical Burn of the Genitalia, Perineum, and Upper Extremities: The Importance of a Multidisciplinary Approach. Journal of Burn Care \& Research, 32, e168-e171. http://dx.doi.org/10.1097/BCR.0b013e31822dc47d

[2] Tran, N.V. (2011) Scrotal and Perineal Reconstruction. Seminars in Plastic Surgery, 25, 213-220. http://dx.doi.org/10.1055/s-0031-1281491

[3] Reid, A.W., Szpalski, C., Sheppard, N.N., Morrison, C.M. and Blondeel, P.N. (2015) An International Comparison of Reimbursement for DIEAP Flap Breast Reconstruction. Journal of Plastic, Reconstructive \& Aesthetic Surgery, 68, 1529-1535. http://dx.doi.org/10.1016/j.bjps.2015.06.025

[4] Schwitzer, J.A., Miller, H.C., Pusic, A.L., Matros, E., Mehrara, B.J., McCarthy, C.M., Lennox, P.A., Van Laeken, N. and Disa, J.J. (2015) Satisfaction Following Unilateral Breast Reconstruction: A Comparison of Pedicled TRAM and Free Abdominal Flaps. Plastic and Reconstructive Surgery-Global Open, 3, e482. http://dx.doi.org/10.1097/GOX.0000000000000458

[5] Mishra, S. and Sharma, R.K. (2009) The Pedicled Thoraco-Umbilical Flap: A Versatile Technique for Upper Limb Coverage. Indian Journal of Plastic Surgery, 42, 169-175. http://dx.doi.org/10.4103/0970-0358.59274 


\section{Submit or recommend next manuscript to SCIRP and we will provide best service for you:}

Accepting pre-submission inquiries through Email, Facebook, Linkedin, Twitter, etc A wide selection of journals (inclusive of 9 subjects, more than 200 journals)

Providing a 24-hour high-quality service

User-friendly online submission system

Fair and swift peer-review system

Efficient typesetting and proofreading procedure

Display of the result of downloads and visits, as well as the number of cited articles

Maximum dissemination of your research work

Submit your manuscript at: http://papersubmission.scirp.org/ 